Boletín de la Sociedad Geológica Mexicana

VOLUMEN 62, NÚM. 1, 2010, P. 199-205

SHORT NOTE

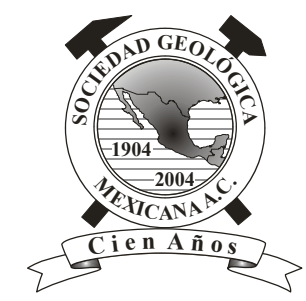

\title{
Jadeitite jade occurrence from the Sierra del Convento mélange (eastern Cuba)
}

\author{
Juan Cárdenas-Párraga ${ }^{1, *}$, Antonio García-Casco ${ }^{1,2}$, Kenya Núñez-Cambra ${ }^{3}$, Antonio \\ Rodríguez-Vega ${ }^{4}$, Idael Francisco Blanco-Quintero ${ }^{1}$, George E. Harlow ${ }^{5}$, Concepción \\ Lázaro ${ }^{1}$
}

${ }^{1}$ Departamento de Mineralogía y Petrología, Universidad de Granada, Fuentenueva s/n, 18002, Granada, Spain.

${ }^{2}$ Instituto Andaluz de Ciencias de la Tierra (CSIC-UGR), Fuentenueva s/n 18002, Granada, Spain.

${ }^{3}$ Instituto de Geología y Paleontología, Vía Blanca y Carretera Central, San Miguel del Padrón, 11000 Ciudad Habana, Cuba.

${ }^{4}$ Departamento de Geología, Instituto Superior Minero-Metalúrgico, Las Coloradas s/n., Moa 83329, Holguín, Cuba.

${ }^{5}$ Department of Earth and Planetary Sciences, American Museum of Natural History, New York, NewYork, 10024, USA.

*cpjuan@correo.ugr.es

\begin{abstract}
A new jadeitite jade locality has been discovered in the serpentinite-matrix subduction mélange of the Sierra del Convento (eastern $\mathrm{Cuba}$ ) in a context associated with tectonic blocks of garnet-epidote amphibolite, tonalitic-trondhjemitic epidote gneiss and blueschist. The jade outcrops occur as blocks surrounded by serpentinite, as late Miocene-early Pliocene detritic sedimentary deposits formed during erosion of the mélange, and as Recent river and beach deposits related to the Macambo and Guardarraya rivers and their mouths. Jade from these outcrops show gem-quality varieties with colours ranging from greenish white to dark green. Potentially, the deposits may be easily exploited. Former exploitation (probably of the beach deposits) by the pre-Columbian Taino inhabitants of Cuba is documented by a large number of jade artifacts (mostly, petaloid axes) found in eastern Cuba.
\end{abstract}

Keywords: Jadeitite, subduction mélange, Sierra del Convento, Cuba.

\section{Resumen}

Una nueva localidad de jade jadeitítico ha sido descubierta en la matriz serpentinitica de la mélange de subducción en la Sierra del Convento (Cuba oriental) en un contexto asociado con bloques tectónicos de anfibolitas con granate-epidota, gneises de composición tonalítica-trondhjemítica con epidota y esquistos azules. Los afloramientos de jade aparecen como bloques rodeados de serpentinitas, como depósitos sedimentarios detríticos de edad Mioceno tardio-Plioceno temprano formados durante la erosión de la mélange, y como depósitos recientes en el río y en la playa relacionados a los ríos Macambo y Guardarraya y sus desembocaduras. El jade encontrado en estos afloramientos muestra variedades de calidad gema con colores que varían desde blanco verdoso hasta verde oscuro. Potencialmente, los depósitos pueden ser explotados fácilmente. Antiguas explotaciones (probablemente, de los depósitos de playa) llevadas a cabo por los habitantes pre-Colombinos Tainos de Cuba están documentadas por el gran número de artefactos de jade (la mayoria, hachas petaloides) encontrados en Cuba oriental.

Palabras clave: Jadeititas, Mélange de subducción, Sierra del Convento, Cuba. 


\section{Introduction}

In the ancient civilizations of Mesoamerica such as the Olmec, Aztec and Maya, jade was highly valued, thus developing the production of decorative artifacts and extending its use as a cure for numerous internal disorders. Spanish referred to the latter as "piedra de ijada", or "colic stone" (Howard, 2002). Currently, the geological and gemological term "jade" includes two different types of monomineralic rocks. Pyroxene jade is jadeite rock (or jadeitite) and amphibole jade is nephrite, a tremoliteactinolite rock. The jadeitite jade is more highly valued as a gemstone or for carving due to its scarcity and greater hardness than the nephrite jade. Recently, García-Casco et al. (2009) described a new locality of jadeitite jade in the serpentinite-matrix subduction mélange of the Sierra del Convento (eastern Cuba). Three types of jadeitite jade occurrences can be identified in the Macambo region of this mélange: 1) as tectonic blocks of 0.5-6 meters in size surrounded by serpentinites (García-Casco et al., 2009), 2) as cm- to m-sized detrital pebbles in late Miocene-early Pliocene conglomerates containing, in addition, pebbles of serpentinite and associated rocks from the mélange, and 3 ) as cm-size pebbles in Recent deposits in the Macambo and Guardarraya rivers and in the beaches formed in their mouths. In this paper, we offer the first characterization of the outcrops and of the different varieties of jade found in these outcrops.

\section{Geological setting}

The Eastern Cuba block extends from the Nipe fault towards the east of the island. It is formed by two large ophiolitic bodies, the Mayarí-Cristal and Moa-Baracoa massifs, and two Cretaceous volcanic arc units known as Santo Domingo and Sierra del Purial complexes (Figure 1a). The magmatic rocks of the ophiolitic massifs have supra-subduction geochemical signatures (Proenza et al., 2006; Marchesi et al., 2007), while the Sierra del Purial complex is peculiar with respect to the volcanic arc units of west-central Cuba because it is metamorphosed to the blueschist facies (Boiteau et al., 1972; Somin and Millán, 1981; Cobiella et al., 1984; Millán and Somin, 1985), suggesting subduction erosion of the arc (Lázaro et al., 2009). The ophiolitic bodies occupy the highest structural position in the region. At the base of the ophiolitic massifs, serpentinitic mélange complexes are locally found (Sierra del Convento and La Corea). These mélanges contain high pressure subduction-related metamorphic exotic blocks (Millán, 1996; García-Casco et al., 2006, 2008a; Lázaro et al., 2009; Blanco-Quintero et al., in press). The Sierra del Convento mélange is located in the south part of eastern Cuba, tectonically emplaced on the top of the Cretaceous volcanic arc complex of Sierra del Purial (Figure 1b).

The Sierra del Convento mélange represents an oceanic subduction channel related to subduction of ProtoCaribbean lithosphere below the Caribbean plate. The first metamorphic products of subduction present in the mélange are early Cretaceous (ca. $120 \mathrm{Ma}$ ) in age. The mélange formation continued until the latter part of the Cretaceous Period (70-65 Ma), when the complex and the associated Sierra del Purial metavolcanic arc complex were exhumed due to an important regional orogenic pulse (García-Casco et al., 2006, 2008a, 2008b; Lázaro et al., 2009). The mélange consists of a serpentinite matrix encompassing tectonics blocks, metamorphosed at high pressure and low to high temperature, of variable composition. These metamorphic blocks comprise lithologies such as amphibolite, blueschist, greenschist, quartzite, impure quartz-feldespathic rocks, meta-greywacke and metapelite, whereas eclogite is rare or absent (Somin and Millán, 1981; Kulachkov and Leyva, 1990; Hernández and Canedo, 1995; Leyva, 1996; Millán, 1996; García-Casco et al., 2008a). The most common rock type is a MORB-derived high-temperature epidote \pm garnet amphibolite, which is typically associated with centimeterto meter-size layers, pockets and veins of leucocratic material of trondhjemitic to tonalitic composition and locally pegmatoid texture. These leucocratic segregations formed upon fluid-assisted partial melting of the amphibolites at $\pm 750^{\circ} \mathrm{C}$ and $14-16 \mathrm{kbar}$, indicating hot subduction of a young oceanic lithosphere (García-Casco, 2007; GarcíaCasco et al., 2008a; Lázaro and García-Casco, 2008; Lázaro et al., 2009). Subsequent exhumation took place in a syn-subduction scenario, allowing the blocks in the mélange to follow counterclockwise $\mathrm{P}-\mathrm{T}$ paths due to continuous cooling of the subduction system. The exotic blocks are concentrated in four different regions at the borders of the Sierra del Convento mélange (Figure 2a). The Macambo region, located south of the serpentinitic body, exposes jadeitite jade blocks and represents the single well documented jade occurrence in Cuba (Figure 2b).

Cobiella and co-workers (1977) described the Punta Imías Formation as the deposits that extend into the coastal strip between the Jauco and Yateras, Yumurí and Miel rivers, in the province of Guantánamo. The terrigenous-carbonate sequence is rich in fossils and consists of clasts of different grain size (including limestone, volcanic, metamorphic and ultramafic rocks), which show coarse to fine stratification (lenticular or parallel) and dark, greyish-yellow, grey or cream colours.

\section{Jade deposits}

Three types of jadeitite deposits can be identified in the Macambo region: 1) in-situ deposits within the mélange, 2) detrital boulders in late Miocene-early Pliocene conglomerates of the Punta Imías Formation, and 3) recent deposits exposed in Macambo and Guardarraya rivers and their mouths.

The in-situ deposits within the mélange consist of 


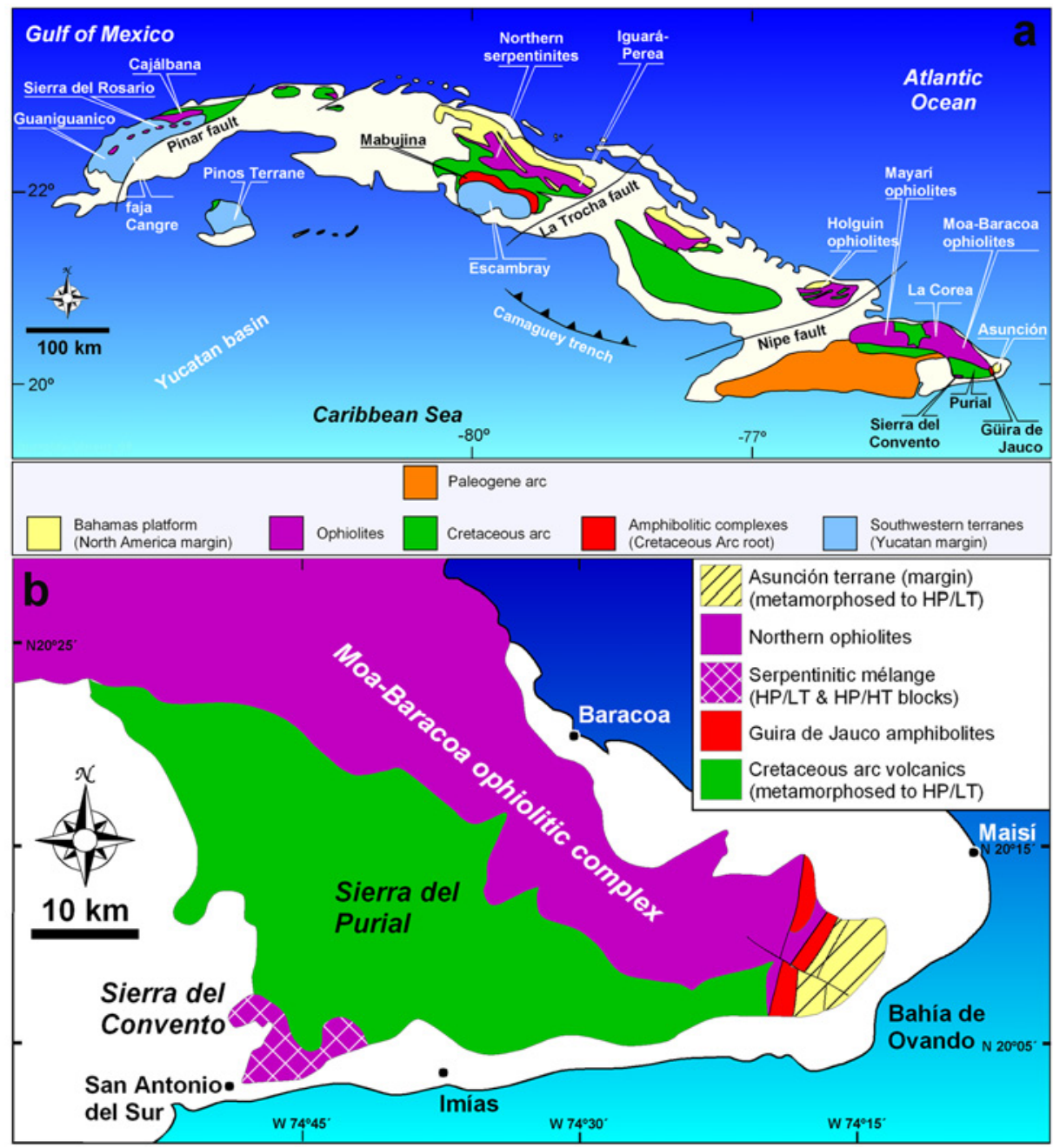

Figure 1. Geological sketch maps of a) Cuba and b) eastern Cuba (after Iturralde-Vinent, 1998) showing location of the Sierra del Convento and major geologic units.
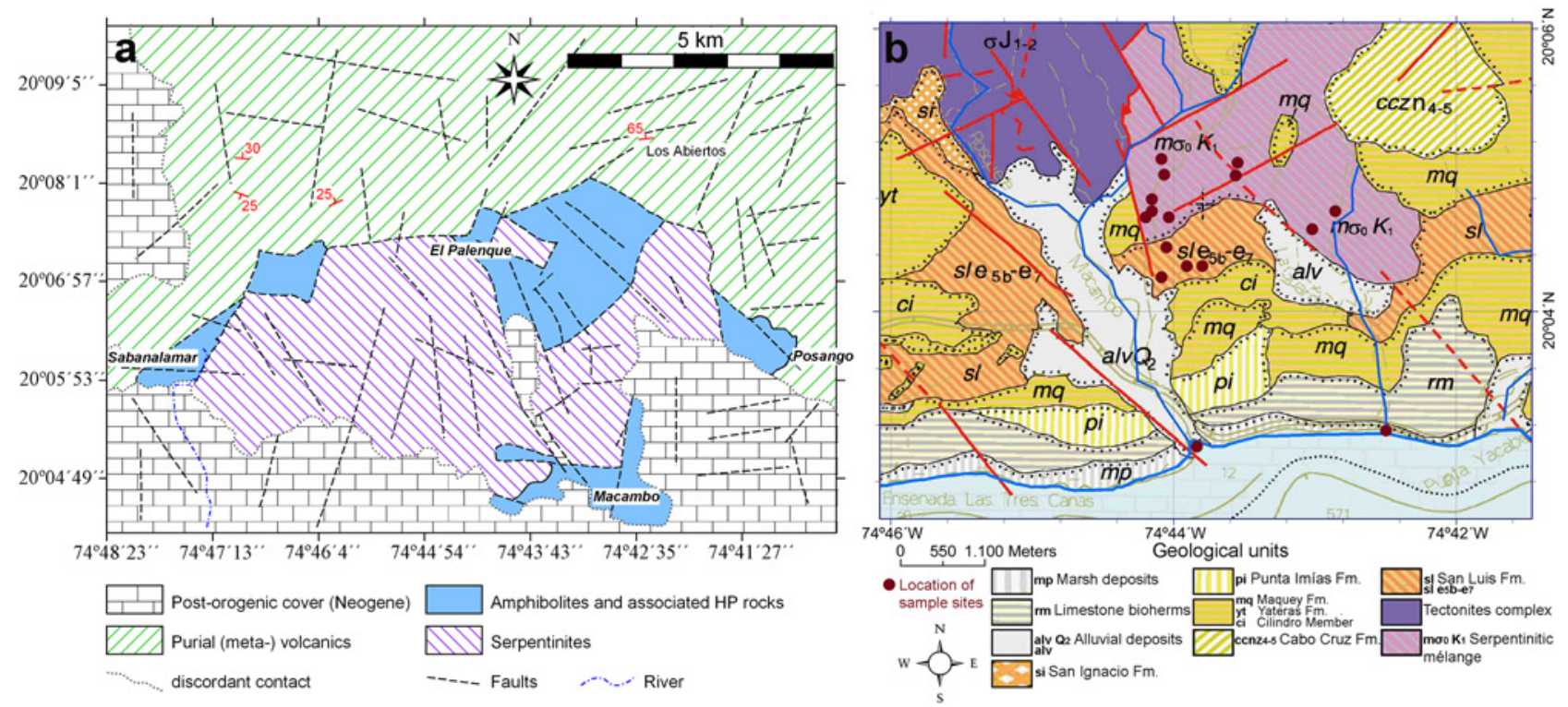

Figure 2. a) Simplified geological map of the Sierra del Convento mélange (Kulachkov and Leyva, 1990) showing four submélange bodies, namely Posango, El Palenque, Sabanalamar and Macambo. b) Geological map of the Macambo area with location of samples sites (IGP, 2007). 

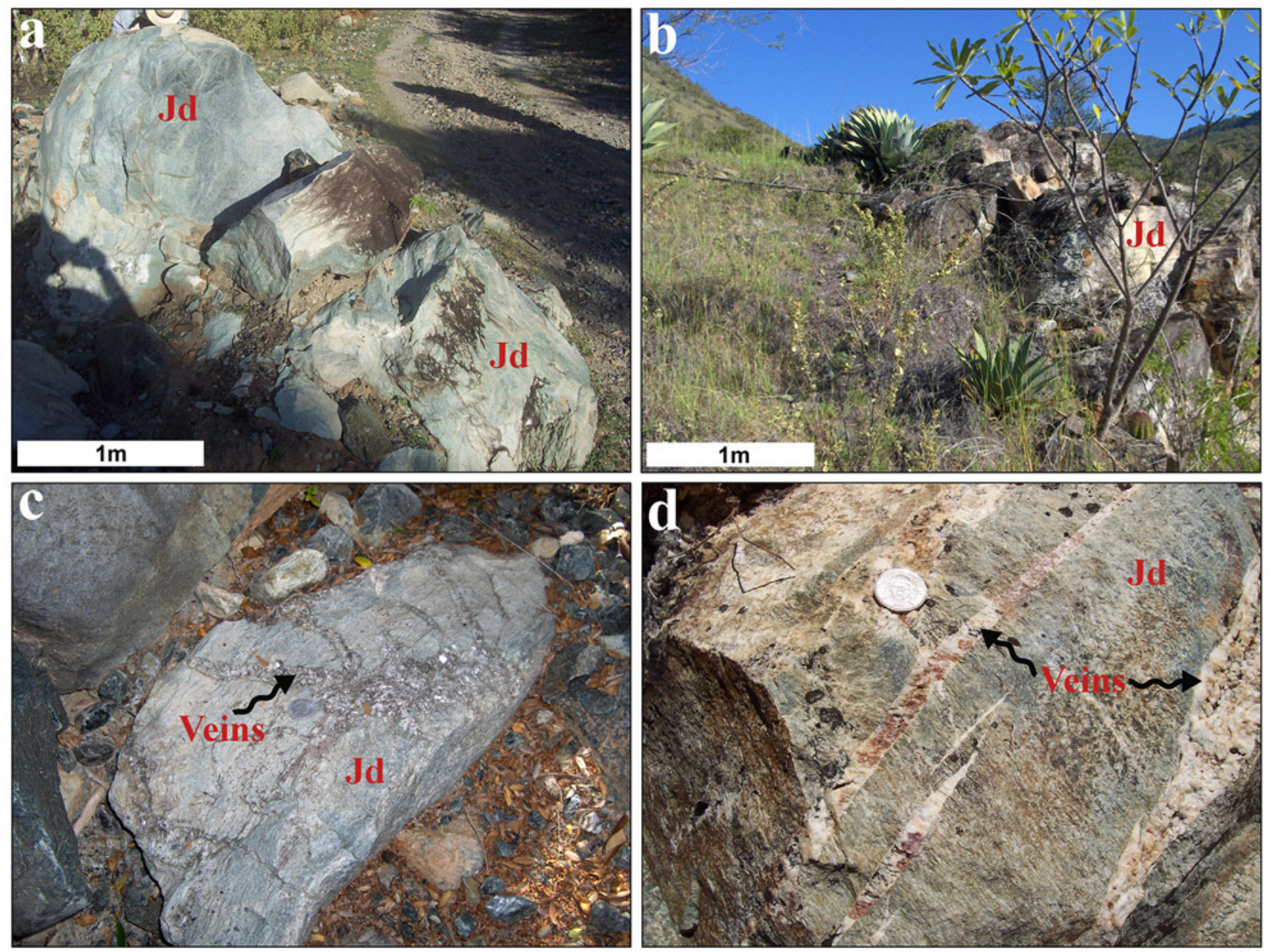

Figure 3. a) and b) In-situ outcrops of isolated jadeitite blocks within the mélange; c) and d) veins of albite \pm white mica in jadeitite blocks.

isolated fine-medium grained, decimeter- to meter-long jadeitite blocks (Figures 3a and 3b). Jadeitite blocks occur closely associated with albitite-, talc-, and chlorite-rich rocks and with tectonic blocks of trondhjemite, plagioclasefree epidote \pm garnet amphibolite, pargasite amphibolitite, (clino) zoisitite, tremolite-actinolite schist, and glaucophane \pm lawsonite schist.

Most jadeitite samples have granoblastic texture, although local brecciation textures are common. Also, crosscutting veins and crusts around the jadeitite bodies are common. They have a larger grain size and are composed mainly of albite \pm white mica (Figures $3 c$ and $3 d$ ). These rocks document late events of fracturing and flow of fluids rich in Na-K.

The late Miocene-early Pliocene conglomerates of the Punta Imías Formation, with a total thickness of about $170 \mathrm{~m}$ (Cobiella et al., 1977), contain cm- to m- sized boulders of varied composition, including jadeitite, within a calcareous clay matrix (Figure 4). The types of jadeitite are similar to those observed in situ in the mélange.

The Recent beach deposits in the mouths of the
Macambo and Guardarraya rivers extend over a distance of 750 and $650 \mathrm{~m}$, respectively. The pebbles are centimeter to decimeter in size on the beach of Guardarraya River, and millimeter to centimeter in size on the beach of the Macambo River (Figures 5a and 5b). Both occurrences are composed of varied lithologies including jadeitite and all types of rocks found in the Sierra del Convento mélange, though serpentinite is dominant.

Taken together, samples of jadeitite from the three outcrops described above have heterogeneous textural and mineralogical composition, but the main variety of gemquality jade is light green, homogeneous with granoblastic texture and fine- to medium-grain size, being formed by 95\% pyroxene (jade \pm omphacite) and albite, phlogopite and epidote (about 5\%) (Figure 5c). Apatite, zircon, titanite, white mica (paragonite and/or phengite), chlorite and dolomite are common accessory minerals. Other varieties of jade have more varied mineralogical contents, with larger amounts of epidote and albite, and colours from greenish white to dark green, bearing heterogeneities such as dark bands and nodules rich in omphacite and white areas richer 

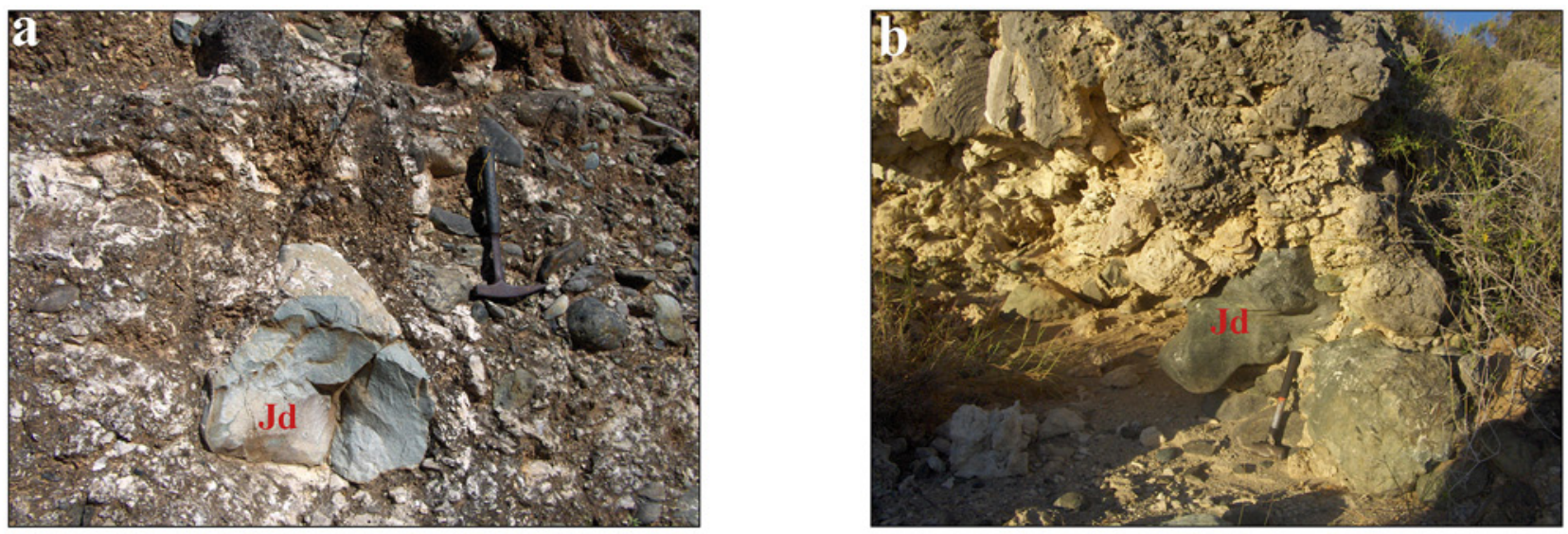

Figure 4. a) and b) Jadeitite detrital blocks (Jd) in the late Miocene-early Pliocene conglomerates of Punta Imías Formation.
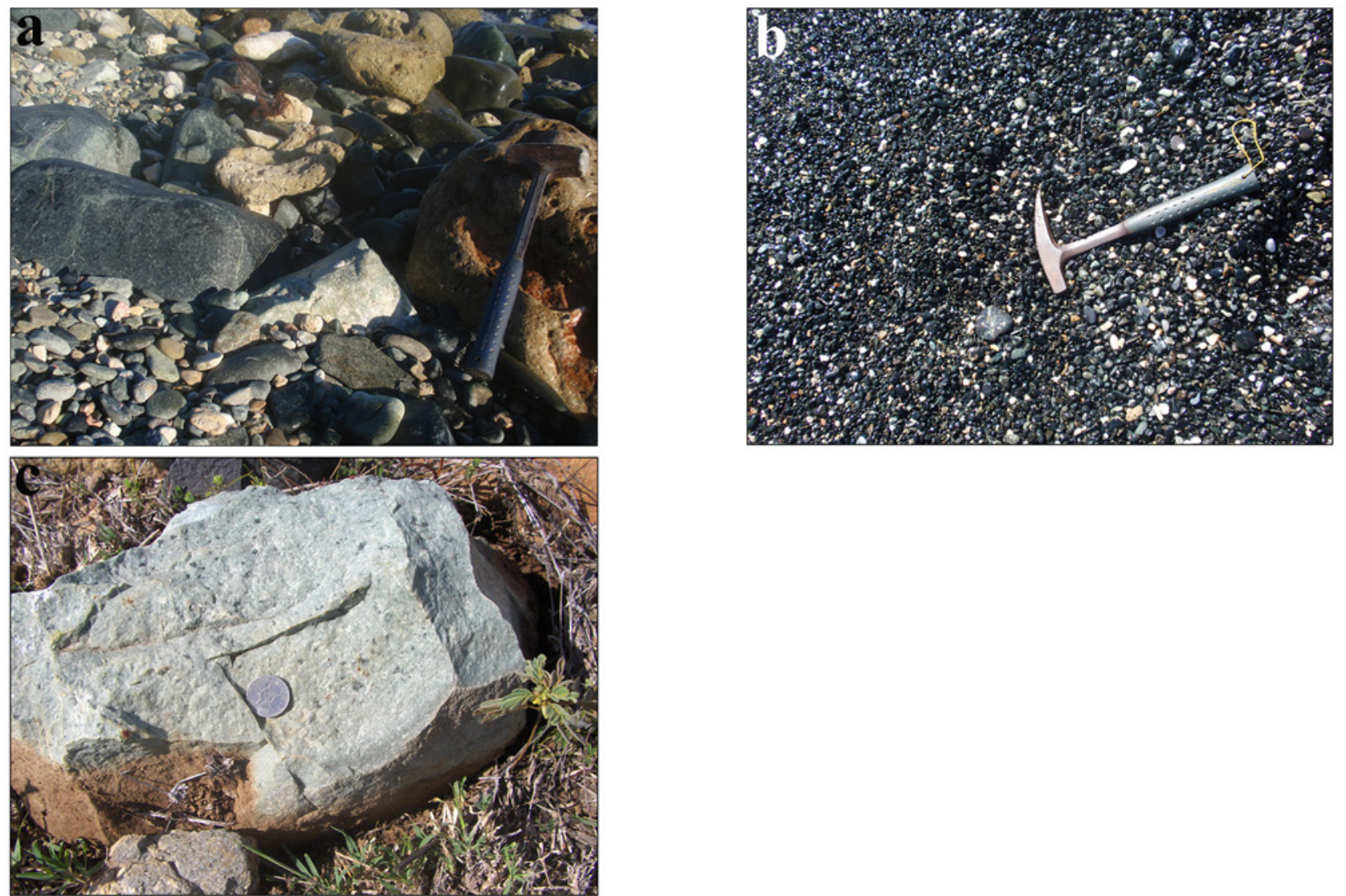

Figure 5. a) Recent deposits on the beach of the Guardarraya River. b) Recent deposits on the beach of the Macambo River. c) Main variety of gemquality jade.

in albite and/or epidote (Figure 6).

\section{Discussion and conclusions}

The origin of jade in the Sierra del Convento mélange is related to fluids evolved in a subduction environment (García-Casco et al., 2009; cf. Harlow and Sorensen, 2005; Sorensen et al., 2006). As discussed by Garcia-Casco et al. (2009), the fluids precipitated jade at high temperature (> $550^{\circ} \mathrm{C}$ ), suggesting a possible genetic link with pegmatitic trondhjemitic melts formed upon partial melting of 

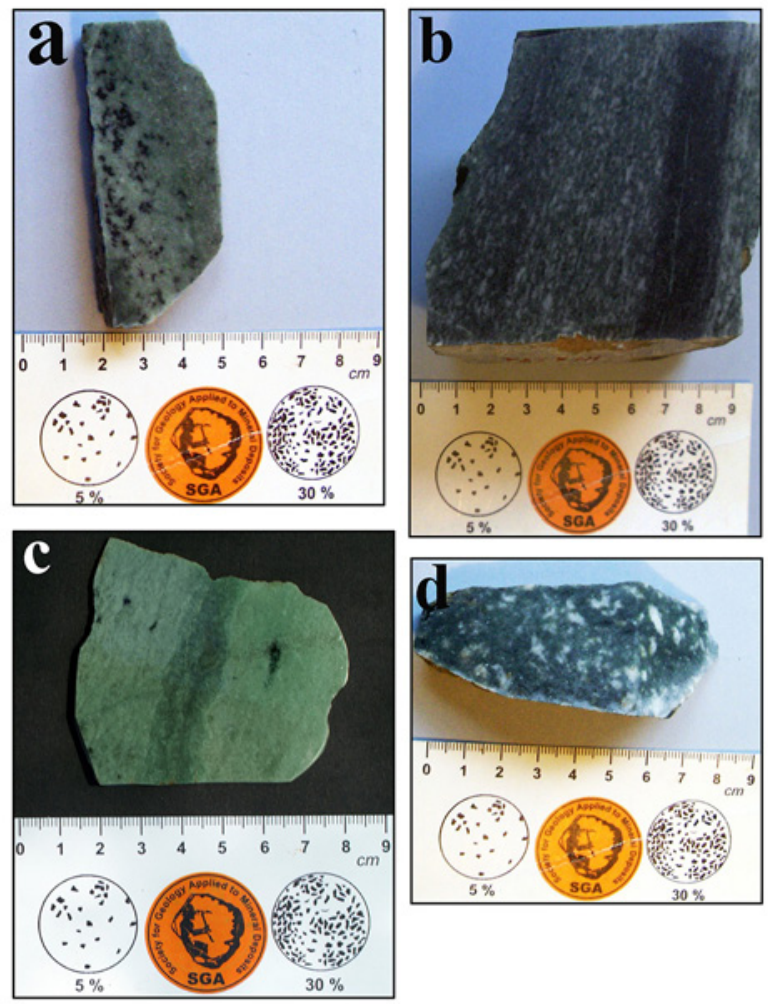

Figure 6. Varieties of jade from Sierra del Convento showing variations in grain size (a, d), and banded structure locally strongly deformed (b, c).

subducted MORB amphibolite deep in the subduction channel. The apparent lack of quartz associated with jadeite indicates a relatively low formation pressure $(<15 \mathrm{kbar}$ at $650^{\circ} \mathrm{C}$ ), in agreement with the conditions of partial melting of amphibolite $\left(15 \mathrm{kbar}, 700-750^{\circ} \mathrm{C}\right)$ and of crystallization of trondhjemitic-tonalitic melts $\left(15-13 \mathrm{kbar}\right.$, about $650^{\circ} \mathrm{C}$; García-Casco, 2007; García-Casco et al., 2008a, Lázaro et al., 2009). Hence, fluids evolved from the crystallizing trondhjemitic-tonalitic magmas may have interacted with ultramafic rocks of the upper plate mantle and deposited jadeitite at high temperature. If confirmed, this hypothesis opens a new line of research concerning the origin of jade.

The Sierra del Convento outcrops bear gem-quality varieties of jade. This, and the large quantity of jade in the deposits, suggests it can be exploited and used in jewelry (Figure 7). We propose that, based on the inhabitants similarities, additional jade occurrences may be discovered in other parts of the Sierra del Convento mélange and in $\mathrm{La}$ Corea mélange (Sierra de Cristal).

From the archaeological point of view, we suggest that the Sierra del Convento outcrops were exploited by the ancient pre-Columbian Taino civilization for manufacturing of artifacts and, perhaps, for trade with other people from the Greater Antilles.

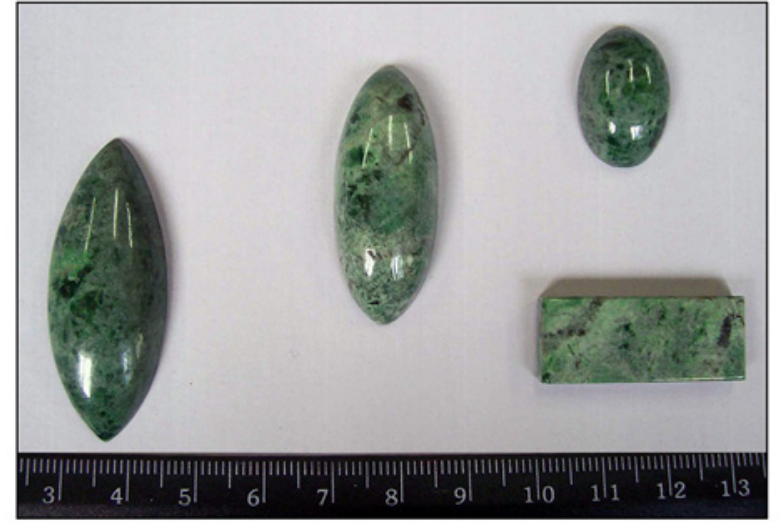

Figure 7. Polished jadeitite jade samples from Sierra del Convento subduction mélange.

\section{Acknowledgments}

This is a contribution to IGCP-546 "Subduction zones of the Caribbean". This paper has received financial support from the Spanish Ministerio de Educación y Ciencia projects CGL2006-08527/BTE and CGL2009-12446/BTE.

\section{References}

Blanco-Quintero, I., García-Casco, A., Rojas-Agramonte, Y., RodríguezVega, A., Lázaro, C., Iturralde-Vinent, M. A., Metamorphic evolution of subducted hot oceanic crust, La Corea mélange, Cuba: American Journal of Science, in press.

Boiteau, A., Michard, A., Saliot, P., 1972, Métamporphisme de haute pression dans le complexe ophiolitique du Purial (Oriente, Cuba): Comptes Rendus de l'Académie des Sciences, Série D 274, 2137-2140.

Cobiella, J.L., Campos, M., Boiteau, A., Quintas, F., 1977, Geología del flanco sur de la Sierra del Purial: Revista la Minería en Cuba, 3, 54-62.

Cobiella, J., Quintas, F., Campos, M., Hernández, M., 1984, Geología de la Región Central y Suroriental de la Provincia de Guantánamo: Santiago de Cuba, Editorial Oriente, $125 \mathrm{p}$.

García-Casco, A., 2007, Magmatic paragonite in trondhjemites from the Sierra del Convento mélange, Cuba: American Mineralogist, 92, 1232-1237.

García-Casco, A., Torres-Roldán, R.L., Iturralde-Vinent, M., Millán, G., Núñez Cambra, K., Lázaro Calisalvo, C., Rodríguez Vega, A., 2006, High pressure metamorphism of ophiolites in Cuba: Geologica Acta, 4, 63-88.

García-Casco, A., Lázaro, C., Rojas-Agramonte, Y., Kröner, A., TorresRoldán, R.L., Núñez, K., Neubauer, F., Millán, G., BlancoQuintero, I., 2008a, Partial melting and counterclockwise P-T path of subducted oceanic crust (Sierra del Convento mélange, Cuba): Journal of Petrology, 49, 129-161.

García-Casco, A., Iturralde-Vinent, M., Pindell, J., 2008b, Latest Cretaceous collision/accretion between the Caribbean Plate and Caribeana: Origin of metamorphic terranes in the Greater Antilles: International Geology Review, 50, 781-809. 
García-Casco, A., Rodríguez Vega, A., Cárdenas Párraga, J., IturraldeVinent, M.A., Lázaro, C., Blanco Quintero, I., Rojas Agramonte, Y., Kröner, A., Núñez Cambra, K., Millán, G., Torres-Roldán, R.L., Carrasquilla, S., 2009, A new jadeitite jade locality (Sierra del Convento, Cuba): first report and some petrological and archaeological implications: Contributions to Mineralogy and Petrology, 158, 1-16.

Harlow, G.E., Sorensen, S.S., 2005, Jade (nephrite and jadeitite) and serpentinite: metasomatic connections: International Geology Review, 47, 113-146.

Hernández, M., Canedo, Z., 1995, Geoquímica de las ofiolitas meridionales de Cuba oriental: Revista de Minería y Geología, 3, 3-9.

Howard, K.B., 2002, Jadeite: Electronic Magazine of the Canadian Institute of Gemmology, Accessed April 2010, Avilable at: http:// www.cigem.ca/431.html.

Instituto de Geología y Paleontología (IGP), 2007, Mapa Geológico Digital de la República de Cuba, scale 1:100 000: La Habana, Cuba, Centro Nacional de Información Geológica, 1 map.

Iturralde-Vinent, M.A., 1998, Sinopsis de la constitución Geológica de Cuba: Acta Geológica Hispánica, 33, 9-56.

Kulachkov, L.V., Leyva, R.C., 1990, Informe sobre los resultados de los trabajos de reconocimiento geológico para cuarzo filoniano en la parte oriental de Cuba: Moa, Cuba, Instituto Superior MineroMetalúrgico, unpublished report.

Lázaro, C., García-Casco, A., 2008, Geochemical and Sr-Nd isotope signatures of pristine slab melts and their residues (Sierra del Convento mélange, eastern Cuba): Chemical Geology, 255, 120-133.

Lázaro, C., García-Casco, A., Rojas-Agramonte, Y., Kröner, A., Neubauer, F., Iturralde-Vinent, M., 2009, Fifty-five-million-year history of oceanic subduction and exhumation at the northern edge of the Caribbean plate (Sierra del Convento mélange, Cuba): Journal of Metamorphic Geology, 27, 19-40.

Leyva, R.C., 1996, Características geológicas, regularidades de distribución y perspectivas de utilización del cuarzo filoniano de la región oriental de Cuba: Moa, Cuba, Instituto Superior Minero-Metalúrgico de Moa, Ph. D. Thesis, 90 p.
Marchesi, C., Garrido, C.J., Bosch, D., Proenza, J.A., Gervilla, F., Monié, P., Rodríguez-Vega, A., 2007, Geochemistry of Cretaceous magmatism in eastern Cuba: recycling of North American continental sediments and implications for subduction polarity in the Greater Antilles Paleo-arc: Journal of Petrology, 48, 1813-1840.

Millán, G., 1996, Metamorfitas de la asociación ofiolítica de Cuba, in Iturralde-Vinent, M.A. (ed.), Ofiolitas y Arcos Volcánicos de Cuba: Miami, Florida, U.S.A., IGCP Project 364 Special Contribution 1: 131-146.

Millán, G., Somin, M., 1985, Nuevos aspectos sobre de la estratigrafía del macizo metamórfico de Escambray. Contribución al conocimiento geológico de las metamorfitas del Escambray y Purial: La Habana, Cuba, Instituto de Geología y Paleontología, Reportes de Investigación de la Academia de Ciencias de Cuba 2, 1-74.

Proenza, J.A., Díaz-Martínez, R., Iriondo, A., Marchesi, C., Melgarejo, J.C., Gervilla, F., Garrido, C.J., Rodríguez-Vega, A., LozanoSantacruz, R., Blanco-Moreno, J.A., 2006, Primitive Cretaceous island-arc volcanic rocks in eastern Cuba: the Téneme Formation: Geologica Acta, 4, 103-121.

Somin, M.L., Millán, G., 1981, Geology of the Metamorphic Complexes of Cuba: Moscow, Russia, Nauka, 219 p.

Sorensen S., Harlow, G.E., Rumble, D., 2006, The origin of jadeititeforming subduction-zone fluids: CL-guided SIMS oxygen-isotope and trace-element evidence: American Mineralogist, 91, 979-996.

Manuscript received: January 5, 2010.

Corrected manuscript received: February 8, 2010.

Manuscript accepted: February 15, 2010. 